\title{
Bodies, morals, and religion \\ Utopia and the Erasmian idea of human progress
}

Han van Ruler

ANTW 108 (3): 321-355

DOI: 10.5117/ANTW2016.3.RULE

\begin{abstract}
Although Thomas More's description of the Utopians' 'Epicurean' position in philosophy nominally coincides with Erasmus's defence of the Philosophia Christi, More shows no concern for the arguments Erasmus gave in support of this view. Taking its starting point from Erasmus's depreciations of the body and More's intellectual as well as physical preoccupations with the bodily sphere, this article presents the theme of the human body and its moral and religious significance as a test case for comparing Erasmus and More. The treatises both men wrote on Christ's suffering in the Garden of Gethsemane confirm that both authors dealt with the notion of the body in contrasting ways: Erasmus shows a tendency to address the moral-psychological question of mentally conquering the worldly self, whilst More highlights the way in which ordinary facts and physical things may carry spiritual and religious meaning. Paradoxically, Erasmus consistently applied his spiritualized ideal of man to this-worldly moral and social concerns, whereas More focused on the physical domain out of a religious interest in transcendent truths. In line with Giulia Sissa's thesis, our hypothesis is that More ostensibly appropriated an Erasmian type of idealism in Utopia, but, contrary to Erasmus himself, focused on the exterior form of a virtuous society, rather than on its moral and spiritual preconditions. While Erasmus advocated a mental transformation towards reason, More's Utopia envisioned what might come of this.
\end{abstract}

Keywords: Utopia, epicureanism, Philosophia Christi, the human body, Christ in Gethsemane, humanism, spirituality, political idealism, moral history 


\section{Introduction}

Was Thomas More ever serious in Utopia? Giulia Sissa, who put forward the idea that the book should be read as part of a literary interplay between More and Erasmus in the wake of Erasmus's Praise of Folly, offers good arguments against taking its moral and political recommendations in any straightforward way as Thomas More's blueprint for a future society. If, as Sissa argues, the figure of Hythloday is an impersonation of Erasmus, we should not identify Thomas More with the idealist he portrays, but rather 'distinguish as sharply as possible' between 'More's authorship of Utopia' and '[the main protagonist Raphael] Hythloday's praise of Utopia'.

In Sissa's reading, More in fact makes fun of Erasmus, some of whose outrageous moral and political ideals he magnifies in return for Erasmus's earlier implication of himself in the excessive mockery of society presented in The Praise of Folly. In what follows, I shall have reason to come back to the issue of how to read Utopia, and add further evidence in favour of seeing More's book as a playful counterpart to the Folly that takes Erasmus's social program to the extreme. I shall not, however, attempt to establish to what extent More himself may or may not have shared views propounded in Utopia. Rather than to concentrate on similarities or differences in their political standpoints, I shall concentrate on the differences of intellectual interest and religious susceptibilities in Erasmus and More.

For this, Utopia will lead the way. If the traveller to Utopia is an impersonation of Erasmus ${ }^{2}$ - and a caricature at that - More's book might seem to offer no indication of his more serious views, no more than Erasmus's Folly might seem to offer straightforward signs of a position in moral philosophy. As we shall see, however, a comparison between More's Utopia and Erasmus's Folly in fact provides us with all relevant clues for a reconstruction of Erasmus's moral themes as well as of More's affiliation to these.

2 Note that the idea of identifying Raphael Hythloday as Erasmus also occurs in Vermeir (2012), who also speculates about the possible relation between Erasmus's notion of the common good and provisions for good government enforced through the Blijde Inkomst, or 'Joyous Entry'Charter of the Estates of Brabant of 1356. Finally, Mancel (2012) adds the names of the Portuguese explorers Duarte Barbosa, next to Duarte Coehlo, as sources of inspiration for the character of the Protuguese sailor in Utopia, and lists references to previous identifications of Raphael as Erasmus (Mancel, 2012: 187-188). 
As I hope to make clear, More was remarkably insensitive to a core aspect of Erasmus's Philosophia Christi, or 'Philosophy of Christ'. Tracing the moral philosophical theme of the body and its pleasures, I shall argue that More showed very little interest in the way in which Erasmus linked the philosophical notion of mental detachment to a moral interpretation of the New Testament message. More's own moral and theological interests were very different, and I shall illustrate the differences between the two humanists on the basis of a comparison of the two parallel treatises in which Erasmus and More both offered their theological views on the question of Jesus's sufferings in Gethsemane. Equally of relevance to the question of judging the moral significance of the body, and unrecognisably far removed from the satirical contexts of Utopia and the Folly, this comparison not only confirms the differences between Erasmus and More, but also indicates a theological incongruity in More that has struck other scholars as well: More's steady attention to the significance of the human body, besides the soul, in matters of devotion. ${ }^{3}$

Contrasting More's way of reflecting on the human body to the stark Christo-Platonism of Erasmus's Philosophia Christi, I also hope to point out how these diverse ways of drawing attention to the physical world ironically illustrate a persistent focus on this-worldly mental aloofness in Erasmus, whilst More, for all his attention to the tangible world, had considerably more otherworldly concerns. In conclusion, I will return to Utopia and discuss the ways in which More and Erasmus may have captured the modern imagination.

Let us begin, however, by taking a look at More's references to the body in Utopia.

3 In a recent volume of Moreana dedicated to 'The Theology of Thomas More', both Beier (2015) and Kelly (2015) come to a similar conclusion. I shall refer to their work where appropriate. Kelly also points out that two of the editors of some of More's Tower Works in the Yale edition made similar remarks. Thus, Clarence Miller, in his Introduction to De Tristitia, writes that '[one] of More's major concerns in the De Tristitia is the attentive reverence, mental and bodily, that Christians ought to cultivate in their prayers' (Miller, 1976b: 723; Kelly, 2015, 124). Reflecting on their different ways of judging the significance of ceremonies, Garry E. Haupt even noted the possibility that More had Erasmus in the back of his mind (Haupt, 1976: cxix; Kelly, 2015: 125): 'Was More perhaps thinking of Erasmus's platonizing when he, in effect turned the tables on the extreme Platonists and insisted, using the Erasmian dichotomy, that ceremony is an aid, not an enemy, to charity?' As I hope to make clear in what follows, there is, indeed, every reason to suggest that More may have been thinking of Erasmus when trying to mitigate purely Platonist readings of Scripture. 


\section{Utopia and Erasmus}

What does Utopia have to say about the body and its pleasures? Apart from the famous passage on the pre-marital inspection of each other's naked bodies by Utopian suitors in the company of 'a sad and honest matron' on the girl's and 'a sage and discreet man' on the young man's side (a 'very fond and foolish' custom to European eyes, in the words of our traveller, Raphael Hythloday ${ }^{4}$ ), Utopia discusses dealings with the human body only incidentally. At the same time, the book offers a fairly comprehensive picture of the Utopian stance towards the pleasures of the body. In his account of Utopian traditions in education, Hythloday discusses not only the islanders' interest in a variety of disciplines, but also the topic of Utopian culture more generally, including an extensive discussion of moral philosophical beliefs.

More has Hythloday recount the Utopians' ethical standpoint in a format that readers with a knowledge of European moral history will recognize as a variation on the Stoic-Epicurean debate on the question of 'ends'. Such a debate, including partisan evaluations of the relative weight of virtue and pleasure in human happiness, had once inspired Cicero and had since been revived in scholastic as well as humanist accounts of the timeless debate on the summum bonum, most notably in Lorenzo Valla. In terms of Greek philosophical standards, the Utopians present themselves as Epicureans: they take pleasure to be the end of moral conduct and the essential element in human happiness. In fact, according to Hythloday, the Utopians

seem almost too much given and inclined to the opinion of them which defend pleasure, wherein they determine either all or the chiefest part of man's felicity to rest. ${ }^{5}$

Raphael's circumspect disclosure of Utopian partiality for Epicureanism is a reason in itself to follow Giulia Sissa and conclude that More is dabbing at Erasmus here. Erasmus himself would only come up with an outright

4 Quotation from Ralph Robinson's $155^{1}$ translation, as included in the Rebhorn edition (More, 2005: 108). In the original, Raphael admits that we (as Europeans) find the practice ineptisimum as well as ridiculum (More, 1965: 186, 188).

5 More (1965: 16o); translation from More (2005: 92). 
identification of Christians and Epicureans in his 1533 colloquy 'Epicureus', in which Hedonius, the champion of hedone ('pleasure'), would argue that 'there are no people more Epicurean than godly Christians. ${ }^{6}$ Yet he had dealt with Epicureanism much earlier, in De contemptu mundi (On Disdaining the World), a work dating back to the late 1480s, and which, as Robert Bultot argued already in 1969, should be characterized as a contribution to the medieval custom of celebrating the joys of monastic life by comparing the delights offered to those who had chosen for the monastery with the pleasures promised in the Garden of Epicurus.

The use of this simile naturally implied that a champion of monasticism sharply distinguished between the base pleasures usually associated with classical Epicureanism and the higher pleasures monks were expected to enjoy. ${ }^{7}$ Such a medieval, adapted version of Epicureanism, tailored to the Christian need of advocating only higher pleasures, would remain Erasmus's preferred interpretation of Epicureanism throughout the rest of his life. Likewise, in the late colloquy 'Epicureus', Hedonius' Epicureanism is itself of this uncommon variety. Whereas Epicureans had traditionally claimed that the end of all human endeavour might be subsumed under a single concept of 'pleasure', Erasmus would always comply to the Christian rule of distancing himself from the original notion of hedone, and take care to emphasize the contrast between what he regarded as common and 'unlawful' forms of pleasure, pleasures that only breed a wretched conscience, and their alternative: the pleasures of the mind. ${ }^{8}$

Around the turn of the century, Erasmus changed his views about the question whom this Epicureanism was meant for. Having become very critical of monastery life not long after he had written De contemptu mundi, he now cautioned his readers against overhasty choices in favour

6 Erasmus (1972: 721). Quotation from Erasmus (1997a: 1075). See also Erasmus (1965: 538).

7 Bultot (1969 : 230-233). Bultot offers a comparison between Erasmus's view and that of John of Salisbury (c. 1115-1176), who also contrasted what Bultot describes as the 'earthly and ephemeral pseudo-values of vulgar Epicureanism' to the 'true, religious and supernatural values' of the 'true Epicurean'.

8 For the reference to 'unlawful' or 'illegitimate' pleasures, see Erasmus (1972: 727; 1965: 1081 and 1965: 544). Erasmus's distinction between two types of pleasure, and his inclusion of an Epicurean understanding of the ultimate good that was taken to refer to mental pleasures only, would soon become a standard way of accepting the Epicurean position along with other philosophical interpretations of moral virtue. See: van Ruler (2009a). 
of monastic life; and he changed the text of De contemptu mundi accordingly. ${ }^{9}$ Far from rejecting his earlier spiritual ideals, however, he simply tossed these over the walls of the cloister, in order to prescribe them to society at large. Was not the whole world a monastery? Erasmus expressly taught it should be so. ${ }^{10}$ As a consequence, his understanding of Epicureanism would, from this point onwards, show up in countless other contexts. In his Education of a Christian Prince for instance, the book he published in the same year in which he published More's Utopia, Erasmus advised the youthful prince that besides the more common pleasures, 'there is another kind of pleasure, which will last, pure and unchanging, all through a man's life." ${ }^{11}$ The Praise of Folly, too, employs a twofold conception of pleasure of which the lower kind is shunned by Christians, whilst the higher type is represented by the pleasures of the mind. It is these latter pleasures which, in this life, offer a foretaste of bliss in the hereafter. ${ }^{12}$

The Praise of Folly has not without reason been held to add to this Christian Epicureanism a further Epicurean element in the form of a sudden debunking of Stoic philosophers, and of other frivolities Erasmus allows himself in the more humorous passages of the work. Since Erasmus's mockery of Stoicism in The Praise of Folly contrasts sharply with the Stoic message he had earlier presented in the Enchiridion, the Handbook for the Christian Soldier of 1503, it has been suggested that Erasmus had meanwhile developed a new interest in Epicureanism, inspired by Lorenzo Valla's

9 After having left the monastry, Erasmus would often express sour views of monks and monkhood and must at some point have decided he should adapt the text of De contemptu mundi. The exact date of the twelfth chapter that he added is unknown, but it may have been written well before the $15^{21}$ publication of the book. It is, on the other hand, most certainly a post-1500 text. Cf. Rummel (1988: 132-133): 'The number of conceptual and even verbal similarities between chapter 12 and other Erasmian writings predating the publication of De contemptu suggest that the epilogue goes back to an earlier period. Indeed, one is tempted to see in it the fragments or salient points of a dissuasoria on the same topic composed in 1506 but now lost.' On the date of the various parts of the 1521 publication, as well as that of the original text, see also Dresden (1977: 34-35).

10 The idea of the whole of Christianity ideally being 'one monastery', is a thought occurring more frequently in Erasmus, for instance in the Letter to Servatius of 1514, Ep. 296, Erasmus (1906: 568), and in the Letter to Paul Volz that was to serve as a Preface to the 1518 edition of the Enchiridion, Erasmus (1913: 374-376; 1933: 17-20).

11 Erasmus (1974: 144). Translation from Erasmus (1997b: 14).

12 Christians, according to Folly, avoid plesaures, yet delight in the spiritual pleasure that is a fortaste of heavenly rewards. Note that Erasmus uses felicitas and praemii (...) illius (...) gustum aut odorem aliquem rather than voluptas to refer to the higher pleasures in this context, and corporis voluptates as well as diliciae for the lower kind of enjoyments. Erasmus (1979: 189, 192193). 
earlier defence of the philosophy. ${ }^{13}$ As I have argued elsewhere, however, Erasmus's and Valla's Epicureanisms ultimately stand worlds apart. ${ }^{14}$ Bringing in his own quasi-Epicurean ideal of higher pleasures in the Platonico-Christian finale of The Praise of Folly (a move that has the effect of a sudden break and a remarkable change of atmosphere in the book), Erasmus simply returns to what had been his position all along, and takes up the defence of the higher pleasures that accompany virtue as a guide for self-conscious beings to make the right choices in life. His serious message for society, in other words, remained exactly the same. Using the concept of 'pleasure' in such a way that it was actually still quite compatible with the Stoic notion of moral worth, Erasmus's position, moreover, was as consistent as - contrary to received opinion - it always was. Despite his jocular pestering of the stony Stoics in The Praise of Folly, he would never seriously denounce Stoicism as a faulty moral doctrine.

In Utopia, Hythloday captures Erasmus's position rather neatly by providing only a fuzzy opposition between the Utopian defence of Epicurean values and what is here presented as 'the contrary opinion', the one that favours 'virtue' and a 'life ordered according to nature' - the Utopian counterpart, in other words, of Stoicism. The text in fact describes both positions in favourable terms. ${ }^{15}$ Taking away the sharp edges of Epicureanism by arguing that the Utopians 'think not felicity to rest in all pleasure, but only in that pleasure that is good and honest', and arguing that, if our reasonable nature kindles in us a love of God and of our fellow men, no less should it be thought to encourage self-help, More in fact gives credit to the Stoic way of thinking even when explaining Utopian Epicureanism. ${ }^{16}$

13 See Panizza (1995). Rather than being 'the last word in the oscillation between Stoic and Epicurean emphases in Erasmus' thought', James D. Tracy, however, argued Erasmus developed a more sympathetic stance towards the masses in between the Enchiridion and the Folly (Tracy, 1972: 124).

14 The Praise of Folly may rightfully be compared to Valla's De voluptate / De vero bono not because Erasmus takes over Valla's position, but because, if we group together the Folly with the preceding Enchiridion, and distinguish within the text of the Folly itself between the playful antiStoicism of the first part and Folly's very serious finale, we do indeed find a triptych in the contents of these works that may count as a variation on the Ciceronian format of a StoicEpicurean debate on ends. Erasmus, in other words, never copied Valla's position, as neither Valla copied Cicero's, but he may well have copied the general set-up. See van Ruler (2009b).

15 See also Mancel (2012: 187): 'Nous pourrions aller jusqu'à proposer que la philosophie des Utopiens dont Hythlodée est plutôt admiratif, rappelle étrangement l'épicurisme vaguement mâtiné de stoïcisme loué et recommandé par Érasme dans son De Contemptu Mundi.'

16 More (1965: 162; $2005: 93)$. 
More may have tried to pick up other aspects of Erasmus's moral philosophy as well. As said (and as Erasmus himself would claim), despite its peculiar style and content, The Praise of Folly remained true to what had been Erasmus's standpoint in the Enchiridion. ${ }^{17}$ It would still be his position in the colloquy on Epicureanism as late as 1533. Yet there were many ways in which Erasmus might dress up his moral philosophical views. If, at times, he defended his position in Epicurean terms, he in fact taught a Platonising and spiritualized form of Epicureanism, and one he held to be compatible not only with all of the major philosophical schools of antiquity, but with the New Testament message as well. For Erasmus, the Christian-Epicurean view that there were higher pleasures to be gained by leading a moral life coincided with what he regarded as the combined message of Greek moral philosophy and Christian theology alike. Along with Platonism and Stoicism, Epicureanism only provided another interpretative scheme with the help of which the application of philosophical reason to all areas of life (and the mental pleasure this was thought to generate) might be contrasted to non-philosophical and non-religious mental attitudes. ${ }^{18}$ This moral dualism, moreover, was based on a firm belief in the strict dualism of body and mind, since, according to a widespread philosophical belief, the use of reason was thought to be impaired only by a mental allegiance to the comforting pleasures associated with the bodily sphere that might obfuscate a clear view of the moral good and thus prevent the agent from attaining a fully rational position. Taking the New Testament contrast between 'the spirit' and 'the flesh' to be a Biblical counterpart to the philosophical distinction of body and mind, Erasmus not only gave a combined, Platonic interpretation to the major philosophical schools of antiquity, but also held the central message of Greek philosophy to be wholly in tune with the New Testament. Indeed, in The Education of a Christian Prince, he even went so far as to profess that '[being] a philosopher is in practice the same as being a Christian; only the terminology is different., ${ }^{19}$

When Thomas More accordingly tells us in Utopia that the Utopians 'seem almost too much given and inclined to the opinion of them which defend pleasure'; that they curiously defend 'so dainty and delicate an

17 See the Letter to Maarten van Dorp, Ep. 337, Erasmus (1910: 93): 'Nec aliud agitur in Moria sub specie lusus quam actum est in Enchiridio.'

18 Though not always very enthusiastic about Aristotelianism, Erasmus even counted the Peripatetic philosophy as a source of philosophical morality, at least in the Enchiridion. Cf. Erasmus (1933: 44). On Erasmus's relation to Aristotle, see: Steel (2009).

19 Erasmus (1974: 145). Translation from Erasmus (1997b: 15). 
opinion' on arguments taken from their 'grave, sharp, bitter [i.e., severe] and rigorous religion'; and never even discuss 'felicity or blessedness' without mixing religion and philosophy, joining 'unto the reasons of philosophy certain principles taken out of religion,' there is every reason to believe that a mock portrait of Erasmus is here being drawn up in the figure of Raphael Hythloday. ${ }^{20}$

At the same time, the way in which Raphael describes the Utopian counterpart to Erasmian Epicureanism suggests that More had no concern for the way in which Erasmus himself would have explained and defended this position. In linking Hythloday to Erasmus, Giulia Sissa has argued that the curious mishmash of a philosophy at once Epicurean and Platonic not only uniquely fits Erasmus, but that it is also a position More deliberately presents as ultimately indefensible. 'Hythloday's argument', according to Sissa, is 'provocative and oxymoronic'; indeed, 'the whole Utopian blend of Epicureanism and Platonism [... s should strike us as utterly absurd.'21

No doubt More himself thought so, too. Yet whether or not he consciously presented the queer notion of a Platonic kind of Epicureanism as a blatant absurdity, he could only do so by disregarding some of the essential elements of Erasmus's actual position. While, on the outside, the Utopian position in moral philosophy fits Erasmus's standpoint in terms of its labels, its mixture of schools and its alignment of philosophy and religion, Hythloday never really ventures to explain in which way these seemingly incompatible labels, schools and areas might combine as they do in Erasmus.

Likewise, in order to explain the idea of a combined philosophico-religious position, More offers only an assortment of the most general religious notions compatible with philosophical views:

that the soul is immortal and by the bountiful goodness of God ordained to felicity, that to our virtues and good deeds rewards be appointed after this life and to our evil deeds punishments. ${ }^{22}$

Explaining Utopian Epicureanism in these terms, More completely bypasses what Erasmus had in mind when presenting himself and his fellow Christians as followers of Epicurus. Nor does More seem very interested in the niceties of Erasmus's interpretation of Epicureanism. In fact, in describ-

20 More (1965: 16o); quotations from More (2005: 92).

21 Sissa (2012: 126-127).

22 More (1965: 16o); quotation from More (2005: 92). 
ing this 'religious' and Utopian form of Epicureanism, More freely plunges into his own stock of associations. His enumeration of non-profitable, i.e. 'foolish' pleasures, for instance, though it may bring to mind Erasmus's mockery of social norms in The Praise of Folly, actually testifies to a typically Morean interest in gluttony, greed and pride, rather than that it offers an Erasmian analysis of lower pleasures. Moreover, though Utopia's description of the pleasures of the mind may remind us of the association Erasmus would later make between illegitimate pleasures and conscience, ${ }^{23}$ bodily pleasures are here explained along the lines of classical Epicureanism, that is to say in terms of dynamic versus static pleasures and of pleasure in general being defined in contrast to pain ${ }^{24}$ - all of which elements are wholly lacking in Erasmus. Nor, finally, do Hythloday's 'Epicurean' interests in the health, sensual awareness and aesthetics of the human body have anything in common with Erasmian moral philosophy. ${ }^{25}$ Indeed, the whole idea of Erasmian Epicureanism had been to draw the attention away from the body and to focus on mental pleasures alone.

\section{Body and mind}

A strong Platonic dualism pervades all of Erasmus's references to Epicureanism, as well as his dealings with Stoicism and his interpretation of the New Testament - indeed all of his philosophical and theological thought. Already in the 1503 Enchiridion, Erasmus had paraphrased biblical expressions from St. Paul, translated them into Greek philosophical language, and used these to interpret spiritual salvation in terms of philosophical detachment. To him, the Platonic distinction of body and mind and the New Testament distinction between the flesh and the spirit exemplified similar anthropological views, with similar moral consequences:

23 That is to say, in his 'Epicureus' colloquy of 1533; see above, note 8.

24 More (1965: 172/173-174/175). Note, however, that More does not seem to follow the Epicureans in their identification of pleasure as an 'absence of pain', at least not if there is no 'presence of health': 'The absence of pain without the presence of health [the Utopians] regard as insensibility rather than pleasure.' More (1965: 175). See Guido Giglioni's article, pp. 399-400, below. 25 Cf. More (1965: 174/175-178/179). 
Paul is engrossed in this point, that we should spurn the strife-ridden flesh and be firm in the spirit, the begetter of love and liberty. On the one hand, the flesh, bondage, unrest, contention are inseparable companions; on the other, the spirit, peace, love, freedom. This is what the Apostle teaches everywhere. ${ }^{26}$

Again, according to the Enchiridion, all details about the philosophical battle between reason and the passions

are taught in the Holy Scriptures, though not in the same terms. What the philosophers call reason Paul sometimes refers to as spirit, sometimes as the inner man, sometimes as the law of the mind. What they call passions he now calls the flesh, now the body, now the outward man, now the law of bodily members. $^{27}$

The result is a very literal form of moral dualism in Erasmus: reason, virtue and piety on the one hand, passion, vice and sin on the other. And since what hindered reason, at least according to the position of classical philosophy, were the passions associated with the body, the human body, in Erasmus, too, is consistently interpreted in a negative sense; as an 'inseparable $^{28}$ source of unrest, and an incessant obstacle to moral enlightenment and religious salvation.

Erasmus further developed this schematisation of traditional moral philosophical and religious intuitions into a theory of mental incentives centred around the Platonic idea of the tripartite soul. Reason, itself identified as the 'immortal soul', is situated in 'the loftiest part of the body [and] the one closest to heaven', while 'the sensual appetite, which lusts for the pleasure of food and drink and which drives us into erotic love' has its place in lower regions, far from 'that divine counsellor presiding in the lofty citadel (...). ${ }^{29}$ Reinterpreting the middle soul in which Plato had seen a natural attendant of reason, Erasmus sometimes evoked the idea of a neutral 'heart' or 'soul' ( anima $^{30}$ ) caught in between the high-rising spirit and the lowly flesh. At other times, however, he interpreted this middle part of the soul as a second level of awareness that, despite the Platonic

26 Erasmus (1933: 82). Translation from Erasmus (1963: 121).

27 Erasmus (1933: 47). Translation from Erasmus (1963: 72).

28 See the quotation referred to in note 26 , above.

29 Erasmus (1933: 43-44). Translation from Erasmus (1963: 66-67).

30 See, for instance, Erasmus (1933: 53). 
characterisation of this part as the 'nobility' within the republic of the mind, Erasmus interpreted in a wholly non-Platonic way as the seat of non-rational factors that may influence human thought and conduct in a manner neither reprehensible nor praiseworthy, but simply natural. ${ }^{31}$

Thomas More had his own particular ways of talking about the body. In an issue of Moreana especially dedicated to the subject of the flesh, Germain Marc'hadour enumerated a variety of different ways in which the human body is explicitly dealt with in More, including religious and moral justifications of the belief that the death of the body is of minor significance in comparison to the life beyond; the Platonically inspired theme (also occurring in Erasmus's Praise of Folly) that life is a preparation for death; the medico-religious conviction, rather prominent in More, that the number of deaths as a result of drinking and eating habits easily exceeds the number of deaths by the sword; as well as a great variety of gluttony-related arguments More had a particular propensity to dwell on. ${ }^{32}$ Finally, since he had a taste for drama both in dress and in demeanour, as well as for overt displays of affection, Marc'hadour also notices a certain susceptibility to 'symbolic action' in More, an aspect of his personality that Marc'hadour seamlessly links to the way in which, for More, physical appearances were intertwined with religious susceptibilities. According to Marc'hadour, More was a 'great actor, in a sacramental world. ${ }^{33}$

Besides for his ways of attaching symbolic meaning to the human body, Thomas More is also well-known, at least in scholarly circles, for the way in which he handled his own. As a piece of uncomfortable undergarment, his famous 'hair-shirt' became the trade-mark of his spiritual mentality, and More is famous besides for having practiced at home the flagellation routine he would continue in his Tower cell. Although it is difficult to estimate how More himself may have experienced and valued these practices, he no doubt saw them as expressions of his religiosity. Pious inspiration for scourging his body may well have been inspired by one or more of his

31 See, for instance, Erasmus (1933: 42) and Erasmus (1979: 171).

32 Marc'hadour (2006-2007). Note that the three bodies Marc'hadour's title refers to are the physical body of man, the eucharist body of Christ, and the mystical body of the Church.

33 Marc'hadour (2006-2007: 104). 
intellectual heroes, such as Thomas à Kempis or Giovanni Pico della Mirandola. ${ }^{34}$ Yet whether or not it was on the authority of others that More sought discomfort and pain, and for whatever intentional reason he did so, we are probably safe to conclude that he must have drawn some emotional stability from being aware of his own body by bearing up with the uncomfortable shirt and by thrashing himself at regular intervals.

The fact of the matter is, that although such practices are nowadays more likely to be interpreted in a sexual context, they have previously been interpreted almost exclusively in terms of a depreciation of the body's sway over the mind, and especially as a form of reducing sexual arousal. ${ }^{35}$ Questioning the biographical value of what Erasmus has told us about the reasons More might have had for renouncing the monastery in favour of a professional career, recent biographers have shown themselves to be disinclined to link More's presumed sexual unease to his bigger choices in life. ${ }^{36}$ Such caution is well-grounded in itself. From the scant evidence that we have concerning More's sexual drive (and here, too, Erasmus may indirectly have been teasing his friend ${ }^{37}$ ), we cannot, indeed, draw any conclusions as to the specific doubts and concerns More may have associated with his sexual inclinations. Yet this does not mean we may not draw other conclusions. We may still, for instance, deduce from

34 The teachings of Thomas à Kempis, whose moving expressions of medieval piety greatly inspired More at least for a certain period of his life, may have influenced him to take strong measures with respect to the subjection of the flesh (Ackroyd, 1998: 98). Arguing that, rather than having been a student of the Heptaplus, of the famous lecture De dignitate hominis, or of any of Giovanni Pico's other major works, More's interest in the celebrated Florentine syncretist was inspired rather by the book that he partly translated into English, Gianfrancesco Pico's Life of his renowned uncle, J.B. Trapp also pointed towards Pico. 'Clear also,' according to Trapp (Trapp, 1991: 127), 'in the letters as in the duodecalogues [writings by Giovanni Pico that More also translated], is Pico's continuing preoccupation, which was also More's, with the need to resist the 'cuppes of Circe, that is to saie ... the sensual affections of the flesh' by, among other things, the mortification of that flesh practiced by both [Pico and More].'

35 The interpretation originally derives from More's first biographers, who alleged that More started wearing the shirt in the sexually most troublesome years of his beginning adulthood. Cf. Ackroyd (1998: 66).

36 The tendency to supress speculation on the issue has been argued either on the basis of an appraisal of More's sense of duty and ambition (Ackroyd, 1998: 99-100), or on the basis of a broader scepticism about the possibility ever to uncover the intentions of our protagonist (Guy, 2000: 28-39).

37 Note that speculations about More's reasons for pursuing a civil career after he had stood on the threshold of the monastery in 1505 were encouraged by Erasmus's comments, in a letter to Ulrich von Hutten of 1519 , that More had not entered the monastery because he had had a greater wish to get married - and thus to be a good husband, rather than 'an impure priest'. Cf. Ep. 999, Erasmus (1922: 18). 
the evidence we have that Thomas More had an acute awareness of his own body and its urges. Rather more to the point with respect to our present purposes, we may suspect that if public display played such a role in More's daily life and if penitence was such an important part of his experience of religion, a far different appreciation of the spiritual relevance of the human body and its engagement in religious life is to be expected in More than in Erasmus, who, ever since he left the monastery only to project an idealised conception of its essence on society at large, would continue to propagate his moral ideals in terms of a mental transformation towards a truly spiritualized form of life - the only stance that might serve as a precondition to moral and social reform according to Erasmus.

More's spiritual writings do, indeed, indicate that the Englishman had very different religious concerns. A fine comparison between Erasmus's rather more 'moral' and More's more 'spiritual' interests may be made on the basis of the tracts they both wrote on the subject of Christ's agony in the garden of Gethsemane. Early on in his career, this was a subject Erasmus had used in order to develop his interpretation of the soul's tripartition and its potential to redirect itself away from the bodily sphere - a theme not only missing in More, but actually at odds with More's way of reading symbolic meaning into the story of Gethsemane.

\section{Lessons from Christ's suffering}

Christ's suffering in the garden of Gethsemane pending his torture, crucifixion, and death is one of Christianity's most dramatic, but also one of its most paradoxical tales. Three of the four New Testament gospels refer to Christ's agony. All three testify that Jesus despaired: he was 'sorrowful and very heavy', 'sorrowful unto death', even 'in agony'. All three gospels, Matthew, Mark and Luke, report the famous words with which Jesus asked his Father to 'let this cup pass from me'. All three recount the words attesting to Christ's eventual acceptance of his plight: 'nevertheless, not my will, but thine, be done.' ${ }^{38}$ Luke even tells us that Christ's agony was so great he sweated blood. ${ }^{39}$ The enigma, and the main reason for so much theological effort being spent on the explanation of Christ's agony, was that there seemed to be no reason for Christ, who is divine, all-knowing and without any sin, to experience any distress. Did he have second thoughts, as it

38 Cf. Matthew 26:36-46; Mark 14:32-42; Luke 22:39-46.

39 Luke 22:44. 
were? Did he try to prevent God from executing what was in stall for him? Did he actually implore his Father to blow the whole thing off? Had he no determination? Was the Son of God reluctant and less brave, apparently, than all those later Christian martyrs who courageously faced and often cheerfully underwent their cruel executions?

Erasmus and More both discussed the New Testament scene in detail, but even More's style is very different from Erasmus's. ${ }^{40}$ Of course, the circumstances in which they were composed - a young Erasmus motivated by the challenge of debating with John Colet on a new area of intellectual inspiration; the old, imprisoned More trying to encourage and reassure himself more than anyone else in preparation for his own impending execution - may explain many of the differences between the two works. Erasmus's Disputatiuncula, or Short Debate Concerning the Distress, Alarm, and Sorrow of Jesus of 1503 , is a polemical work, whilst De Tristitia Christi, or The Sadness of Christ (1535), More's final essay, was arguably the least academic of his works. Written in his Tower cell, this meditation on Christ's suffering was deliberately intended to ease his own torment and the misery of his imprisonment. ${ }^{41}$

This does not alter the fact that both treatises offer a fine illustration of the varying ways in which the two humanists theologically employed their mind-body dialectics. As the editor and translator of De Tristitia Clarence Miller has argued, the clarity alone with which the text of More's manuscript was produced 'should serve to correct any tendency to overstress the purely personal and biographical significance' of the work. ${ }^{42}$ Moreover, even if More, when writing De Tristitia, was primarily concerned with consoling himself, it is not in this regard that his text differs from Erasmus's. Had Erasmus primarily been playing the intellectual game of disputing subtle theoretical points with fellow theologians, More's aim was clearly not so much to draw on the comparison between himself and Christ, but rather to produce a more indirect form of consolation and inspiration for author and reader alike. At every stage in its argument, $D e$

40 Erasmus is so smart as to tackle his potential critics in advance by admitting that his own base rhetoric cannot compare to the deep theological knowledge of his friend John Colet, to whom his essay was initially addressed. Cf. Erasmus (1704: 1290; 1988: 66). More, by contrast, employs rhetorical techniques not so much in order to strengthen his argument, but to kindle the imagination of his readers, and thus to bring about a shared amazement at the facts and details of the story recalled.

41 See the Letter to Margaret, nr. 56, in More (1961: 225). On the creation of the book during More's confinement, see also Miller (1976), as well as Baker House (2008).

42 Miller (1976: 748). 
Tristitia seems committed to moving the reader - and, no doubt, the author himself - towards a sense of wonder at the deep truth of Scripture. As Marie-Claire Phélippeau has written:

Even in his most moving passages, the Sadness of Christ, for instance, More writes for an audience, giving lessons, inciting his readers to believe and pray, and to reform their souls. More writes in the pastoral $(. .$.$) mode. { }^{43}$

Besides this, we also see a clear theoretical parting of ways, in that Erasmus and More apply the dualism of body and mind, the Platonic theme they were equally prone to read into the New Testament dualism of the flesh and the spirit, in wholly divergent ways. It was in his Short Debate Concerning the Distress, Alarm, and Sorrow of Jesus, in fact, that Erasmus initially took up his Platonic anthropology in order not only to explain the effects of a partly human nature that might solve the riddle of Christ's suffering, but also to explain in detail the differences that separate Christ's position from ours. In reaction to an alternative reading that had been accepted by John Colet, and according to which Christ's agony was not occasioned by his impending torture and death, but by a concern for the fateful future of the Jews, the lot of the apostles and the pending doom over the city of Jerusalem, Erasmus defended the more common-sense view according to which Jesus simply feared his own predicament. Erasmus thus attributed human emotions to Jesus, and interpreted Jesus's suffering as a personal sacrifice that allows humans to identify themselves with Christ, to sympathize with him, and to see him as an example to be followed.

Such an interpretation naturally implied that Erasmus highlighted the notion of Christ's double nature: both human and divine. This in itself was a standard element in scholastic theology, and Erasmus made sure explicitly to mention his allegiance to the scholastics in this matter. ${ }^{44}$ What the Disputatiuncula added to such long-standing theological views was a philosophical comparison between the mind of Christ and those of ordinary human beings.

Despite being human, Christ was not, of course, merely human. This, amongst other things, traditionally explained the obvious difference there is between Jesus's agony and the courageousness of human martyrs: whereas martyrs may receive divinely induced forms of support, Jesus -

43 Phélippeau (2015: 144).

44 Erasmus (1704: 1290; 1988: 66). 
at least in this particular context; the context of the Passion - wishes to emphasize his humanity. ${ }^{45}$ In Erasmus, this leads to further psycho-philosophical speculations about how this works, and to an explanation of the way in which Jesus and common mortals differ. In order not to have to attribute sinful weaknesses to Jesus, Erasmus emphasized that Christ experienced only natural fears and it is here that he presents the full armature of his Platonic anthropology, drawing a sharp line between the 'natural' and the 'moral' realms, coinciding with the division between realms that are relevant and realms that are indifferent to questions of morality. ${ }^{46}$ The point is that Jesus never needed lower drives to experience genuine fear, since the fear of death, for instance, may be experienced purely on the basis of the neutral 'middle' soul.

Focusing next on the question of overcoming fears and steering one's own conduct, the Platonic anthropology also occasioned Erasmus to add some conclusions on morality as such. The crucial difference between Jesus and humans with respect to the way in which indecision and a wavering of the will may be handled, is that Jesus may allow conflicting mental propensities to continue to exist within his mind without any consequence to his ulterior behaviour. He may at once experience the type of human feelings with which he is able to identify with us - and with which he is able to appeal to our imagination - and still keep himself from being led astray by them, since he will always choose to act according to his divine nature and will. Thus, in Christ, two natures may lead to conflicting experiences without any loss of serenity. As Erasmus puts it, Jesus 'feared death, and did not fear it. He dreaded it, and did not. He desired it, and did not.' $^{47}$

In man, however, conquering the self is not that easy. Indeed, in human experience, genuine conflicts arise, as the one proclivity tends to extinguish the other. Our passions, accordingly, may overpower us. And even if they do not, there is still an ongoing struggle between our various inclinations, and always a fight to be won. Erasmus thus comes to reflect on our own moral selves through the example of Jesus. Contrary to present-day emotivist conceptions of morality, he held that it is only mental struggles that delineate the realm of the moral. To fight one's inclinations, appetites

45 Accordingly, even though a lesser charity could help martyrs overcome their agony, the infinitely greater charity and highest pleasure in Christ himself to comply with divine will and thus save humanity, could exist in Christ alongside the most horrific pains he experienced in so far as he was human. Cf. Erasmus (1704: 1279; 1988: 43).

46 Erasmus (1704: 1272; 1988: 27-28).

47 Erasmus (1704: 1283). Translation from Erasmus (1998: 52). 
and temptations calls for a special effort, a form of bravery that may make us virtuous. No virtue, however, is found in following one's natural endowments. The greater one's dread, the more virtuous one's ultimate bravery. ${ }^{48}$ And since it is only by conquering 'lower' drives that human virtue may exert itself, Erasmus estimates that, contrary to the case of Jesus, human mental battles will never end, but will continue throughout life - which, for Erasmus, is a reason to revert to the Stoic example of the soldier who is judged for either defending or leaving his post - never for crying or for turning pale. ${ }^{49}$

Like Erasmus, More attributed human emotions to Jesus and saw his suffering as a source of moral inspiration. Like Erasmus, he also distinguished Jesus's plight from that of human martyrs and highlighted the double nature of Christ. Nor was More an average theologian himself. Indeed, searching for hidden truth in Scripture, he does more, in De Tristitia, than simply weave symbolic meaning into the facts of the biblical story. Rather, Christology turns into metaphysics here, as More continuously emphasises that there are two separate realms of activity in Jesus's handling of the situation in Gethsemane: the worldly and the divine. From this viewpoint, More frankly addresses sceptical objections as well, such as the question why Jesus, if he truly is God, should return to his disciples after having prayed further afield no less than three times, only to find them sleeping. Why should he have to express his wish for them to stay awake, if he could see to this himself? Being God, why did he not simply enforce what he was now repeatedly asking for with such an apparent lack of success? More's answer is that there is such a thing as wishing and wishing: of course Christ can accomplish his own wishes 'in an absolute and unqualified sense.' In the present case, however, Jesus's wish is qualified, since the wish for his disciples to comply involves his wishing that they wish the same themselves. ${ }^{50}$

Even within Divine Will, one may thus distinguish absolute from qualified demands, and God's wish for us to cooperate and to comply, is a qualified wish. In More's analysis, however, such a standard philosophical distinction forms part of a broader strategy with which he aims to highlight the dual character of recounted facts and their deeper meaning. Indeed, the whole story of Gethsemane would be pointless without the duality of Christ, who, as God, aims to awaken in us a trust, inspired by the example

48 Cf. Erasmus (1704: 1275; 1988: 34-35).

49 Erasmus (1704: 1273; 1988: 30).

50 More (1976b: 199; 1993: 34). 
he presents to us - as man. The meaning conveyed in the angel coming down to console Christ is, accordingly, not to detract from Christ's divinity. Rather, 'just as He wished to undergo sadness and anxiety for our sake, so too for our sake He wished to have an angel console Him'; it is both to show himself as 'truly man' and to 'give us hope' that we, too, may receive consolation (provided that we imitate him by 'sighing and praying from the bottom of our hearts', as More typically adds), that the angel comes to play a role as well. ${ }^{51}$

At other instances, Jesus may simultaneously be acting out both sides of his twofold nature - a tactic that More makes fully explicit where, in the Biblical account of Gethsemane, Christ takes the lead in the process of his own capture, and, 'coming up close to the crowd, asks "Whom do you seek?"' When the cohort replies 'Jesus of Nazareth', he tells them: 'I am $\mathrm{He}^{, 52}$ and More now tells his readers how mistaken it was in the first place to object to an apparent weakness in Christ; look at the courage he now shows! It was, in effect, an overwhelming display of courage, since, as Scripture recalls, all those who attended 'drew back and fell to the ground.' 53

This particular passage incites More to reflect on the disparity between Jesus and the others present at Gethsemane, since it is exactly by revealing himself through the physical body of a human being that 'Christ proved that He truly is that word of God which pierces more sharply than any twoedged sword. ${ }^{54}$ The original manuscript of De Tristitia proves that More considered adding further symbolic interpretations of the crowd's fearful reaction to Jesus, but ultimately chose not to speculate on its relevance for questions of the afterlife. If, however, it is More's custom to concentrate on Old Testament similarities and on moral interpretations, rather than on speculations concerning the life beyond, ${ }^{55}$ we must understand 'moral' here to mean 'inspirational' in a very broad sense. There is no tendency in More to develop a fuller understanding of human morality as such - not, at least, in the way Erasmus did when he made use of the events at Gethsemane for drawing a comparison between human conduct and divine. Rather than the contrast between the human and the divine, it is the

$51 \quad$ More (1976b: 225 and 227; 1993: 39).

52 More (1976b: 417; 1993: 75).

53 More (1976b: 417 and 425; 1993: 75 and 77).

54 More (1976b: 425; 1993: 77).

55 Cf. Clarence Miller, who writes, with respect to More's deleted jottings in the manuscript, that ' $(. .$.$) they belong to the anagogical level of interpretation, whereas More, when he goes$ beyond the literal, seems to prefer the typological and tropological.' Miller (1976: 751). 
combination of divine and human aspects in Christ that carries most significance for More, just as he shows a tendency in De Tristitia to find meaning in the combination of the mental and the physical, the body and the mind, rather than in the contrast between them. References to the body occur in De Tristitia for instance with respect to typical Morean themes such as the pre-eminence of the eternal life over the present. Likewise, the conclusion of his curiously elaborate discussion regarding the identity of the youngster who ran away naked from the scene at Gethsemane, is that the death of the body is of no great significance, since the body may be shrugged off as easily as a loincloth. ${ }^{56}$

De Tristitia, however, is never disparaging of the body as such, nor of its moral significance. As Benjamin Beier noted with respect to the young man fleeing naked from the Garden of Gethsemane, the body is expressly described as a 'garment' of the soul here, and is used to announce the 'new body' to be won in the hereafter. ${ }^{57}$ More's theological interest in the body has struck other scholars as well. Michael Kelly recently argued that, for More, '[salvation] is not for souls alone', ${ }^{58}$ whilst Beier went on to observe that More 'manifests a particular interest in and appreciation for the body as a consecutive part of the whole human being. ${ }^{59}$ This, indeed, is a significant feature of De Tristitia in comparison to Erasmus's treatment of Gethsemane. More's treatise, in fact, touches upon the idea of a spiritual coordination of body and mind in a very explicit way where More evokes the topic of symbolic meaning, a topic for which the story of Christ's vigil and arrest is eminently suited, as it hinges on the dualism of Christ's nature - and thus on the duality between the worldly and the divine. ${ }^{60}$

The point comes out sharply where More addresses the story of Peter severing Malchus's ear in a powerless attempt to change the divinely ordained course of things. According to all four gospel accounts, Christ at this point rebukes Peter for attempting to prevent what the arrest team have come to do, namely to seize him and to take him away. 'Do you not know,' Christ asks his overenthusiastic disciple according to the gospel of Mat-

56 More (1976b: 565-617; 1993; 104-112). The conclusion deals with a theme also mentioned by Marc'hadour in his enumeration of topics More habitually associated with the body. See note 32 , above.

57 Beier (2015: 89-9o); More (1976b: 605; 1993; 110-111).

58 Kelly (2015: 128).

59 Beier (2015: 84).

6o Beier adds that the analogy itself between Christ's humanity and the human body (More, 1976b: 181; 1993: 30) 'ensures the body's dignity' - a confirmation of More's way of valuing the body's spiritual significance in De Tristitia that I had not noticed myself. Cf. Beier (2015: 88). 
thew, 'that I could ask my Father for help and He would immediately deliver to me more than twelve legions of angels?' ${ }^{61}$ To set himself free, Jesus had much better options, in other words, than to let Peter cut off Malchus's ear. The point is that this is not what is supposed to happen from God's point of view. In order to stifle any speculation as to why he would not save himself, Christ rhetorically asks how otherwise the Scriptures would be fulfilled that 'say this is the way it must be ${ }^{62}$ More neatly contrasts Peter's ill-timed worldly engagement with the divinely ordained course of things by arguing that what Peter attempts to solve on the level of human accomplishment goes against what, on a higher plan, God has in store for humanity at large. In staging the events at Gethsemane, God occasions what is crucial to the salvation of mankind, and even if, like Peter, we try with good intentions to interfere on Christ's behalf, such human acts will always be weighed against the divine plan that may lie hidden, but is everywhere alluded to in Holy Writ.

The story of Malchus's ear occasions More to find further layers of Scriptural symbolism that need not concern us here. ${ }^{63}$ What does matter, is that despite a Platonically-inspired moment in which he associates the name of 'Malchus' (meaning 'King') with the notion of Reason, More is not at all tempted to develop a Platonic account of higher and lower mental drives in man, as Erasmus would certainly have been tempted to do at this point. More, by contrast, has his own way of inserting the topic of mind and body into the passage, making explicit the comparison between body and soul on the one hand, and literal and allegorical meanings of Scripture - or, as More puts it, 'spiritual mysteries' - on the other. The story of Malchus's ear brings More to such levels of hidden meaning, that it comes to be more than simply an example of literal happenings and hidden implications. For More, it is also an occasion to discuss the more general theme of divine mysteries continually adding to the literal account of Biblical events, and it is the all-pervading and enlivening power of the soul that is here compared to the omnipresence of deeper layers of meaning in Scripture. Indeed, as More puts it, 'no factual account in all of

61 More (1976b: 495; 1993; 91). Cf. Matthew 26:53.

62 More (1976b: 501; 1993; 92). Cf. Matthew 26:54.

63 With respect to Malchus, More develops a line of argument that is actually rather farfetched in its way of seeking symbolic meaning. Indeed, the reference to the notion of reason through the name of Malchus, who ought to have obeyed this 'King' instead of rebelling against him, is almost awkward in its way of taking Malchus himself for the divine road he should follow. More (1976b: 509-515; 1993; 93-95). 
Scripture is so gross and corporeal (so to speak) that it does not have life and breath from some spiritual mystery. ${ }^{64}$

What is 'corporeal' in this context - as against what provides 'life and sensation' or 'life and breath', and is therefore akin to the soul $\left(\right.$ anima $\left.^{65}\right)-$ is not the mental disposition standing in the way of what is holy and reasonable; it is simply the potentiality of palpable facts to be pervaded by hidden meaning. As his hero St. Augustine will have taught More, it is the promise of literal affairs and dealings hiding deeper layers of meaning that renders the theme of body and mind particularly applicable as a philosophical metaphor equal to the New Testament topic of the flesh and the spirit. Because of the emphasis on the co-occurrence and coincidence of what are in fact two separate levels of causality, worldly and divine, the topic of body and soul here gives expression to the doublelayered structure of the events themselves, and thus develops into a kind of a meta-metaphor, in which the soul acquires the symbolic meaning of meaning itself, and the body that of its token or container.

The body at the same time being a symbol for man's humble station in comparison to God, More does not address the relation of body and mind in order to draw up an anthropology that might function as a basis for morality, but only in order to associate the body, just as he consequently associates words and names, with the symbolic and spiritual meaning that the sphere of the factual and the physical ultimately carries with it. ${ }^{66}$ For Thomas More, the web of references hidden in Scripture is always an occasion to reflect on the duality between the observed facts and the deeper meaning behind the scenes, as it were. It is in this sense, too, that the notion of the body functions symbolically in More's theology as a stepping stone towards the divine.

64 More (1976b: 505-507; 1993; 93).

65 More (1976b: 505 and 507; 1993; 93).

66 Note that Benjamin Beier, who also comments on this passage, concludes that 'the whole passage affirms the body's goodness and expresses the difficulty involved in giving a precise account of the relationship between, not just the ordering of, body and soul.' Beier (2015: 93). Michael Kelly, for his part, concludes that 'Thomas More's ideas about the role of material things in the economy of salvation represent elements of a coherent Incarnational theology that views matter as a natural tool in the divine plan of redemption.' Kelly (2015: 134). 


\section{Erasmian humanism and Utopia}

In his recurrent attacks on legalism and ritualism, Erasmus might at times equally advocate a figurative reading of Scripture, and use the New Testament theme of the flesh and the spirit as a model for distinguishing allegory from literalism, rather than reason from irrationality. Thomas More, on the other hand, never makes the opposite move; from allegory to moral psychology. Discussing More's various ways of reflecting on the body, Germain Marc'hadour, in the article referred to above, even observed that the whole notion of the tripartite soul is missing in the works of More:

The subdivision of man into body, soul and spirit, so explicit in 1 Thessalonians 5:23, is reflected in both [John] Fisher and Erasmus, but does not seem to have entered into More's categories. ${ }^{67}$

The reason was not that More did not know his Bible. Rather, the difference between Erasmus and More on this point indicates that whereas theology always meant philosophy to Erasmus, it did not necessarily do so for More. Neither, therefore, was More inclined to read Plato into St. Paul in the way Erasmus did. Explaining the theologically pressing question of how Christ allowed himself, as a divine person, to experience specific parts of human emotional life in his 'final' hours on earth, Erasmus typically turned his attention to a moral philosophical analysis of mental fights aimed at achieving victories over the lower self. In More's Tristitia, by contrast, references to the metaphor of body and soul primarily served to highlight the hidden meaning of Scripture, so that More might attach to the physical world a deeper, religious significance. Whereas for Erasmus the soul was primarily involved in a continued fight against the body, for More the body primarily figured as the organic bearer of religious symbolism and spiritual meaning.

Returning to Utopia, we may now conclude that More fitted the image of a worldly hedonist as little as Erasmus himself. But where does this leave us with regard to our interpretation of the utopian dream? Is not Utopia at least better adapted than the Folly to awaken in a present-day readership the notion of a political dreamland, since it alludes to a joyful Epicurean future on earth, whereas Erasmus' book ultimately conveys only a rather sombre message of Platonico-Christian renunciation? And how can it be 
that Utopia's moral philosophy and social optimism seem to fit neither Erasmus, nor More?

One way to answer these questions, is to argue that what More and Erasmus wished for was somehow fundamentally at odds with what they believed in. In an interesting book on Erasmus, More, and the idea of a Utopia, Hanan Yoran has recently suggested that there is an internal contradiction to 'Erasmian humanism' as such. Erasmian humanism, according to Yoran, was a unique, politically charged type of humanism of which Erasmus and More were the main representatives. ${ }^{68}$ The movement was characterized by a radical and activist agenda in favour of social change, but ultimately failed to provide a viable program for this, since our Erasmian humanists were unable to conceptualize political ideals that were too much at variance with the epistemological and ethical presuppositions of the intellectual universe they inhabited. ${ }^{69}$ Humanism, according to Yoran, rejected (scholastic) metaphysical categories, bridged the gap between 'the symbolic and the "real", and refused to accept 'the traditional distinction between the vita activa and the vita contemplativa' ${ }^{70}$ Erasmus and More were both humanists, but their universalist political ideas did not fit their humanism - which is why Erasmus's and More's works, according to Yoran, are full of inconsistencies. Erasmus - to name only some of the examples Yoran presents as symptoms of the contradictions internal to his humanist activism - was ultimately ambivalent about monarchical rule; dismissed in his political writings historical sources he elsewhere prescribed as educational tools; and, as the famous colloquy The Godly Feast indicates, could only fathom his own ideals to be realised in the secluded area of a country house meeting of humanist friends. ${ }^{71}$ The retreat from the world in The Godly Feast, in particular, when moral and political views were supposed to be put into practice in European society at large, is symptomatic, according to Yoran; it is a 'fictive - but ultimately deceptive - refuge from the harsh truths about the impotency of Erasmian Humanism. ${ }^{72}$ Likewise, More too, or so Yoran claims, subverted and undermined

68 In Yoran's formulation, 'Erasmus and his followers created a humanist Republic of Letters as a relatively autonomous sociointellectual space. They created the social identity, embodied first and foremost by Erasmus himself, of the universal intellectual whose sole concern is the wellbeing of Christendom as a whole.' Yoran (2010: 37).

69 According to Yoran, the idea of the universal intellectual was an idea that 'violated the basic epistemological and ethical presuppositions' of humanist discourse.' Yoran (2010: 9).

70 Yoran (2010: 3-5); quotation from Yoran (2010: 4).

71 Yoran (2010: 108-109, 111-112, and 121-131).

72 Yoran (2010: 129). 
humanist discourse itself by his leanings towards Erasmian humanism; first by offering no solution to his own 'bleak diagnosis of the political reality' in Richard III; and then, in Utopia, by writing a book that contradicts humanist institutions and practices at all levels, through its elimination of all cultural and symbolic forms of meaning from the economy, ethics, and social order of Utopian society. ${ }^{73}$

Are Erasmus and More really to be charged of undermining the 'ontology of humanist discourse ${ }^{74}$ ? Such a conclusion is unnecessary, I think, if only because the contradictions Yoran notes may quite easily be explained in the light of what we have been discussing. As for Erasmus, there is no need to question the consistency of his social program as such. Rather than the first modern intellectual, ${ }^{75}$ Erasmus was a Christian philosopher. Not only did this make him less interested in political questions such as whether to support a monarchy or a democracy, it actually rendered this question more or less pointless. In The Education of a Christian Prince, Erasmus openly expressed his regret at the fact that Europe's monarchs were not chosen. ${ }^{76}$ Yet in Erasmus's religiously inspired version of political idealism, this was in any case a question of minor concern, since whether it is the king who rules, or the nobility, or the people, what counts for Erasmus is that they do so according to reason. Given the fact that there are hereditary princes, Erasmus's political treatise proposes to make good statesmen out of these rulers. Yet to follow Christ is everyone's cause, according to Erasmus. Presenting the novel idea of a universal spiritual edification, all his works envision the formation of a social and political culture based solely on the morality of its individual members. Rather than the rule of kings, the rule of citizens, or even the rule of law, what mattered to Erasmus was the rule of ethics. This was also the ideal Socrates had once dreamt of. As a political goal, it may be said to have been Plato's objective as well, but it was an idealism seriously applied to society at large only in post-Erasmian Europe.

There is thus no inconsistency in Erasmus's way of addressing the rulers rather than the multitudes of his times. Nor did he have any doubts about what to teach a Christian Prince. Rather than being an inconsistent humanist on the basis of his choice of classical sources, Erasmus had perfectly

73 See Chapters 5 and 6, respectively, in Yoran (2010); quotation from Yoran (2010: 158).

74 Yoran (2010: 182).

75 Note that, to Yoran's eyes, the internal contradictions in More's and Erasmus's socio-political humanism was a first sign of the internal paradoxes 'characteristic of the position of the modern intellectual'. Yoran (2010: 187).

76 Erasmus (1974: 136-137). 
good reasons to dismiss in his political writings the kind of historical sources he may elsewhere have prescribed as educational tools. Julius Caesar, for example, might well have written a very readable Latin, but this did not make his expansionist ideas suitable reading materials for the moral education of a young monarch. Finally, the ideal setting of a gathering of humanist friends, though of course no guarantee for political changes in society, was exactly the kind of small-scale example for the large-scale development of a pious mental attitude that Erasmus wished to export from the confines of the monastery to the Christian state as a whole.

More, likewise, was never untrue to his Renaissance times. His theological works indicate that, for all the presumed bleakness of his depiction of the court of Richard III, or his model society in Utopia, there is little reason to attribute to him a humanistic program of political engagement that is at odds with the Renaissance tendency to attach symbolic significance to social institutions or historical events. Despite his legal and historical interest in human acts and political dealings, his religious motivations always left More plenty of room for distinguishing a level of divine orchestration that might give meaning to both political history and individual human lives. In his religious works we accordingly meet a Thomas More who cares neither for historical realism nor for philosophical idealism in themselves, as much as he cares for the possibility always to attest to a deep faith in the divine administration of things - a faith that no less allowed him to be realistic, devotional and ironic at the same time. ${ }^{77}$

There were indeed many ways of being a humanist, and if we wish to value the significance of the humanist tradition for political history, a first thing to notice is that, instead of denoting a shared epistemology - let alone a common 'humanist ontology' - the fuzzy category of Renaissance humanism in fact accommodated a great variety of philosophical and political views. With respect to More's penchant for realism and Erasmus's idealism, there is extra reason to reflect on the Dutchman's interest in moral philosophy and More's interest in historical writings. In questions of morality and politics, such a diversity of interests could easily result in an intellectual responsiveness to either the notion of human perfectibility or the idea of human incorrigibility - especially so in humanist times, when scholars might develop a distinct fascination with either ancient

77 In the recent Moreana issue on 'The Theology of Thomas More', various contributions reflect on the role of humour in More's otherwise very serious works on religious questions. See the reference to the issue in note 3 , above. 
philosophers or classical historians. It is not without reason that Machiavelli's Prince of 1513, to take the most obvious example of political 'realism', and Erasmus's Education of a Christian Prince of 1516 are often presented as complete opposites on the spectrum of the realism-idealism debate. ${ }^{78}$ In this case, too, positions taken to be representative of either a 'realist' or an 'idealist' interest in politics were to a large extent sustained on the basis of a diversity of literary interests, and this should not surprise us. Whereas historical sources tend to encourage - as well as to confirm the legitimacy of - a certain naturalism towards the description of human conduct, moral philosophy is 'idealistic' in and of itself. In Renaissance Europe, anthropological convictions may often have dwelt unconsciously, but my impression is that the disciplinary divide - along with other factors, such as religious convictions ${ }^{79}$ - often inspired anthropological beliefs as well, ranging from naïve optimism to a dark pessimism with regard to the betterment of man. ${ }^{80}$

Early-modern realism and idealism might thus, amongst other things, reflect an ambiguity within Renaissance culture itself,, ${ }^{81}$ but with respect to More and Erasmus it will, I think, ultimately be more profitable to consider another aspect of their intellectual concerns: Erasmus's preoccupation

78 According to its modern editor, Erasmus's Education of a Christian Prince, 'takes precisely the opposite point of view' with respect to what 'Machiavelli set out to define.' Jardine (1997: vi and vii). The difference between the two, one might say, is that Erasmus offers a 'moral' view on politics, which is to say, a view on politics in which the Prince is told that he should follow certain moral standards, whilst Machiavelli, on the other hand, presents a view of princes not so much as they should be, at least not according to ethical standards, but as they have historically presented themselves. For an elaboration of the realism-idealism theme, as well as a further comparison of Erasmus and Machiavelli, see also Erik De Bom's article in this volume.

79 Blaise Pascal's anti-humanist stance in moral philosophy is a telling seventeenth-century example of a religiously inspired scepticism vis-à-vis moral philosophical views. See van Ruler (2009).

80 Significantly, it was another adept of the historical tradition, Thomas Hobbes, who would later make explicit the opposition between his own realist views and the idealist conclusions of the philosophers: 'the Felicity of this life, consisteth not in the repose of a mind satisfied. For there is no such Finis ultimus, (utmost ayme,) nor Summum Bonum, (greatest Good,) as is spoken of in the Books of the old Morall Philosophers.' Hobbes (1981: 16o). See also van Ruler (2009). For further criticisms of philosophical idealism by authors within the historical tradition, see also the examples of Machiavelli and Lipsius referred to in Erik De Bom's article, below.

81 Although this is no immediate reason to deny More any moral or political optimism, or to attribute to him a harsh realism comparable to that of Machiavelli or Hobbes; and although the contrast between More and Erasmus is of a subtler nature than that between Erasmus and Machiavelli - and thus more difficult to determine - we should neither underestimate the potential depth of More's irony vis-à-vis Erasmus on the basis of their disparate historical and philosophical interests. 
with a this-worldly application of religious maxims and More's concern for purely transcendent, rather than socially relevant forms of salvation - a contrast that runs parallel to the contrast between their personality traits and religious susceptibilities, rather than their literary interests. It is in their theologies that their personalities show. Despite the fact that our two 'Oxford Reformers' shared many important intellectual standpoints and opinions, especially with respect to the application of a humanist methodology in theology, ${ }^{82}$ More and Erasmus were ultimately theologians of rather different sorts. If Erasmus was a very activist and rather philosophical type of theologian, Thomas More, although a lawyer by profession, was himself not only a theologian at heart, but a very contemplative and soul-searching theologian at that.

The contrasting ways in which we saw Erasmus and More deal with the Biblical theme of Christ's suffering offers a graphic illustration, to my mind, of the dissimilar religious susceptibilities between the two friends. Where Erasmus's Christian sentiment was driven by a this-worldly interest in moral and social reform, More had a special penchant for a symbolic reading of everyday experience. Paradoxically, their humanist ways of expressions could equally serve both causes. Whenever Erasmus propounded the moral and political belief in a transformation of society based on the mental transformation of its individual members, he might do so in some of the most ethereal terminology provided by the moral philosophical and theological literature, and allude to Platonists and Christians as a class of likeminded people who were as dead to the world as they were ecstatic in

82 As adherents of the 'new learning' and fellow-representatives of the party that valued the Greek New Testament over the Vulgate, and prioritised an interpretation of its message tailored to everyday concerns, Erasmus and More also followed John Colet in his critical stance towards religious practices affected by ritualistic credulity. More, accordingly, often expressed religious concerns very similar to those of Erasmus, especially in the years immediately following the publication of Utopia. Nor could he, as his famous Letter to a Monk demonstrates very clearly, be lured into distancing himself from the Erasmian cause. I cling to the expression 'Oxford Reformers' since I feel it neatly captures the fact that John Colet played a pivotal role in encouraging both Erasmus and More to develop an alternative to scholastic ways of theologizing as well as to thoughtless ritualism in religion. Cf. Seebohm (1971). Note, however, that Seebohm's epitaph 'Oxford Reformers' has become less current today than it originally was, no doubt due to a present taste for less Wiggish interpretations of the period. Describing the cultural situation in early sixteenth-century England, J.B. Trapp, for instance, proposed to give the name of 'London humanists' to the party of Grocyn, William Lily, Colet, More and Linacre, 'as they are best called, rather than the Oxford Reformers', reserving the title of 'early Tudor Humanists' for the threesome that, as in Seebohm's case, form the primary subject-matter of his book. Trapp (1991: 15). 
their minds. Yet in all of such cases, including the finale of The Praise of Folly, these views no less remained part of a decidedly this-worldly project of social change. More, on the other hand, had very different religious interests. Indeed, the same biblical verse of 1 Corinthians 2:9 that tells us of the unimaginable joys God has prepared for those who love him, might be put into the this-worldly context of mental pleasures experienced by the virtuous in Erasmus, ${ }^{83}$ whilst serving only to sharpen the contrast between this life and the next in More. ${ }^{84}$

It is here that Giulia Sissa's thesis may be of most significance. What if Utopia, instead of embodying More's own program for public reform, either ironically addresses the de facto otherworldliness of Erasmus's moral concerns, or benevolently tries to contribute in More's own personal way to Erasmus's program of social improvement? As I have said at the outset, I shall not here attempt to settle the question to what extent Utopia may reflect More's own political views. Rather, I shall round off with a reflection on how Utopia might be situated historically in view of the differences between More and Erasmus.

\section{Conclusion}

However one might interpret More's stance towards Erasmus, I take it that Utopia was the best thing More could think of in replying to The Praise of Folly. In Utopia, More involved Erasmus in a playful publication just as Erasmus had involved him a few years earlier in his Folly. More's book does not do what Erasmus aimed to do himself, since it never seriously addresses the topic of a transformation of individual minds as a precondition for social reform, nor the idea of that, in respect of the higher goal to further the rule and triumph of reason, philosophy and religion coincide. More simply had no affinity with these topics, just as, in his theological works, he shows no concern for any practical or moral, rather than strictly spiritual, motivations for mastering the self.

This leaves us with a variety of possibilities with respect to the way in which More positioned himself vis-à-vis Erasmus in Utopia. If he wished to be critical of his friend, for instance because he did not share Erasmus's optimism about the perfectibility of man, More may still have designed Utopia as an alternative to Erasmus's program; an alternative that argues in

83 Erasmus (1933: 120; 1979: 193; 1972: 730).

84 More (1976: 309). 
favour of changes to be made in the organisational set-up of society, rather than the mental make-up of man. ${ }^{85}$ One might also consider the possibility that, fully in line with More's other intellectual pursuits, Utopia supplements Erasmus's moral concerns with a focus on the physical rather than the mental issues involved in thinking about society. Thus, Utopia's emphasis on the corporeal side of human well-being, including its preoccupation with agricultural and economic conditions, might be read as an alternative to Erasmus's more ethereal interpretation of human perfectibility. ${ }^{86}$

One may also read the whole book as a parody, but there is room for a further alternative. Since there is no reason to doubt that both authors, as well as Peter Giles, the third friend involved, were all rather pleased with More's text, one might also read Utopia not so much as a criticism of, or a substitute to, Erasmus's views, but simply as a representation of Erasmian utopianism in a style adapted to More's own interests. Whatever Thomas More himself may ultimately have thought of its content, Utopia may then offer an intriguing picture of what, according to More, was Erasmus's position, or of what, according to More, might result if Erasmus's reasonable Paradise were ever realised. In this sense, Utopia is a dummy-type description of Erasmian social reform. If it did not offer anything much by way of a Philosophia Christi, Erasmus may still have agreed to many of its futuristic ideas, even if they here come in the guise of social constraints rather than reasonable choices.

Erasmus may also have liked More's description of what an Erasmian future would look like, even if we do not. Modern doubts about the seriousness of Utopia's vision of the future are often inspired by the fact that present-day readers see many downsides to the ideal state it describes. If we assume, as Paul Turner does in his introduction to the Penguin edition, 'that Utopia is what it appears to be, a blueprint, however provisional, for a perfect society, ${ }^{87}$ then why is it that the island of Utopia strikes us as anything but a Land of Cockaigne? Or why is it that, as Hanan Yoran noted, 'many of the ideal state's practices are oppressive and brutal even by nonutopian standards'? ${ }^{88}$ One solution to this problem is to see Utopia 'though the eyes of its author, against the background of Tudor England,' as

85 This is the position taken by Erik De Bom in his article on 'Realism vs Utopianism', below.

86 This would be in line with Guido Giglioini's reading. Note that, in his article on More and Smith, Giglioni argues that 'as an attempt to solve the problem of a generalized condition of dearth, Utopia is first and foremost about hunger.' See below, p. 397.

87 Turner (2003: xvii).

88 Yoran (2010: 165). Yoran (2010: 165-177) offers an extended discussion of discontents with the Utopian dream. 
Paul Turner suggests. ${ }^{89}$ This, indeed, is a promising stratagem for interpreting More as well as Erasmus. In 1516, Utopia's strict social rules would have offered large parts of the population an unprecedented sense of security. Its idea, moreover, to give offenders official warnings first and only relatively lenient penalties later, would have come as a welcome substitute to the widespread torture and indiscriminate hangings in Renaissance Europe. ${ }^{90}$ In this sense, More's Utopia was politically ahead of its times as much as Erasmus himself was.

Yet there is a deeper paradox to this kind of historical comparison, since it not only tells us about pre-modern ideals, but just as much about ourselves. If we wish to explain the ongoing popularity of such exceptional works of Renaissance literature as More's Utopia and Erasmus's Folly, we must also ask how the way in which we judge them relates to our own moral and political preferences.

The reasonable hedonism of the Utopians may easily be interpreted along the lines of a conception of human happiness and in terms of individual freedoms we are generally very fond of today. Yet our own ideals of freedom are as alien to Utopia as they were alien to both More and Erasmus. The Epicureanism More sketches was neither his own, nor in all respects that of his friend, but what is more important, is that the personal freedoms we are likely to associate with individual liberties, such as the free choice and free expression of individual preferences in dress, political ideas, as well as in moral and sexual comportment, or the ideal of being able to maximise one's positive (though possibly idiosyncratic) emotions, are wholly exempt from Utopia, as they are exempt from the Folly, and from any pre- or even early-modern moral or political treatise. It is not that Erasmus or More disliked freedom, but that their concept of freedom was very different from ours. Classical and early-modern authors were inclined to interpret the notion in terms of the mental autonomy to comply to a moral imperative, rather than in terms of the possibility to adhere to personal preferences.

The contradiction is thus neither in Erasmus or More, but in the contradictory moral demands addressed by Renaissance authors yearning for a moral society on the one hand, and post-Romantic concerns addressed by

89 Turner (2003: xviii).

90 To quote Turner's marvellous Introduction once more: 'Compared to the nightmarish quality of regal tyranny during the period, the pressure of public opinion in Utopia does not seem so very terrible; and if adulterers have a rather hard time there, at least they are not disembowelled alive, as More might easily have been, or, like three Carthusian monks convicted of the same crime, kept standing bolt upright in fetters and iron collars for seventeen days.' Turner (2003: xx). 
educated individuals arguably already living in a social Paradise on the other.

Virtue came first. If we judge Utopia's relation to political history from this perspective, we may see how it in fact pictures the realisation of Erasmian moral and religious ideals in an entirely honest way. It may well be that it does so by offering a bleak picture of society, but this is not the result of any inherent contradiction within the Renaissance world-outlook. Rather, its matter-of-fact presentation of Utopian customs reflects the down-to-earth character of the issues someone like More or Erasmus might have liked to see changed.

In the attempt to bring his contemporaries to a higher level of moral awareness, Erasmus consistently invited his fellow Christians to redirect their mental energy towards an application of Christian piety and philosophical virtue in all manners of life. If such a strategy may have seemed idealistic at the time, there is every reason to be careful about calling it 'idealistic' in hindsight. Erasmus himself would have been totally amazed if he could have witnessed the level of education of later generations, their interest in questions of justice, or the daily business of millions of professionals in our own day and age who would never even dream of being corrupt. Judging from The Education of a Christian Prince, with its emphasis on educating the Prince in such a way that he might secure the common good by a focus on revenue and taxation, on infrastructure and a strict regulation of the magistracy, as well as on good education and the rule of law, rather than on family interests and wars of succession, we may well ask whether it was not Erasmus who ultimately proved to be more of a realist - at least in comparison to his pessimistic contemporary Machiavelli, whose political views are hardly of relevance for understanding civil society.

One might pose a similar question with respect to Erasmus and More. If Utopia's ongoing appeal rests first and foremost on its presentation of a fully realised political Paradise, we may well ask which of the two ideas has had most cultural significance five hundred years beyond: Erasmus's utopian program of mental transformation and educational reform, or More's sample vision of an Erasmian society? Either way, both ideas have been remarkably effective since 1516 . Whereas Erasmus only advocated a mental transformation towards reason, Utopia may well have been conceived first and foremost as a good-humoured, possibly even charitable, prediction of what might come of this. 


\section{Bibliography}

Ackroyd, P. (1998) The Life of Thomas More. London: Chatto \& Windus.

Baker House, S. (2008) Endgame: The Genesis of More's The Sadness of Christ, Moreana 45 (174), pp. 33-53.

Beier, B.V. (2015) Anthropology through Analogy: Thomas More's Body Metaphors in De Tristitia Christi, Moreana 52 (199-200), pp. 83-94.

Bultot, R. (1969) Érasme, Épicure et le 'De contemptu mundi, in: J. Coppens (ed.), Scrinium Erasmianum. Leiden, pp. 205-238.

Dresden, S. (1977) Introduction, in: D. Erasmus, De contemptu mundi, Opera Omnia Desiderii Erasmi Roterodami, series V, vol. 1. Amsterdam and Oxford: North-Holland Publishing Company.

Erasmus, D. (1704) Disputatiuncula de taedio, pavore, tristitia Jesu, instante supplicio crucis; Deque verbis, quibus visus est mortem deprecari, Pater, si fieri potest, transeat a me calix iste, in: D. Erasmus, Opera Omnia, vol. 5. Leiden: P. vander Aa, 1704.

Erasmus, D. (1906) Opvs Epistolarum Des. Erasmi Roterodami, vol. 1, ed. P.S. Allen. Oxford: Clarendon.

Erasmus, D. (1910) Opvs Epistolarum Des. Erasmi Roterodami, vol. 2, ed. P.S. Allen. Oxford: Clarendon.

Erasmus, D. (1913) Opvs Epistolarum Des. Erasmi Roterodami, vol. 3, ed. P.S. Allen. Oxford: Clarendon.

Erasmus, D. (1922) Opvs Epistolarum Des. Erasmi Roterodami, vol. 4, ed. P. S. Allen. Oxford: Clarendon.

Erasmus, D. (1933) Enchiridion militis Christiani, ed. H. and A. Holborn, Ausgewählte Werke, Band 1. Munich: Beck.

Erasmus, D. (1963) The Enchiridion of Erasmus, ed. R. Himelick. Bloomington: Indiana University Press.

Erasmus, D. (1965), Epicureus, in: The Colloquies of Erasmus, ed. C.R. Thompson. Chicago and London: The University of Chicago Press, 1965.

Erasmus, D. (1972) Epicureus, in: Opera Omnia Desiderii Erasmi Roterodami, series I, vol. 3, ed. L.-E. Halkin, F. Bierlaire and R. Hoven. Amsterdam: North-Holland Publishing Company.

Erasmus, D. (1974) Institutio Principis Christiani, in: Opera Omnia Desiderii Erasmi Roterodami, series IV, vol. 1 ed. O. Herding. Amsterdam: North-Holland Publishing Company.

Erasmus, D. (1977) De contemptu mundi, in: Opera Omnia Desiderii Erasmi Roterodami, series V, vol. 1, ed. S. Dresden. Amsterdam and Oxford: North-Holland Publishing Company.

Erasmus, D. (1979) Moriae encomium id est Stultitiae laus, in: Opera Omnia Desiderii Erasmi Roterodami, series 4, vol. 3, ed. C.M. Bruehl and C.H. Miller. Amsterdam and Oxford: NorthHolland Publishing Company.

Erasmus, D. (1988) On Disdaining the World, in: Collected Works of Erasmus, vol. 66, ed. J.W. O'Mally. Toronto, Buffalo, and London: University of Toronto Press.

Erasmus, D. (1997a) Epicureus, in: The Colloquies, in: Collected Works of Erasmus, vol. 40, ed. C.R. Thompson. Toronto, Buffalo and London: University of Toronto Press.

Erasmus, D. (1997b) The Education of a Christian Prince, ed. L. Jardine, transl. M. Cheshire and M.J. Heath. Cambridge: Cambridge Univesity Press.

Erasmus, D. (1998) A Short Debate Concerning the Distress, Alarm and Sorrow of Jesus, in: The Collected Wors of Erasmus, vol. 70, ed. J.W. O'Malley. Toronto: University of Toronto Press.

Guy, John (2000) Thomas More. London: Arnold.

Hobbes, T. (1981) Leviathan, ed. Crawford Brough Macpherson. Harmondsworth: Penguin. 
Jardine, L. (1997) Introduction, in: D. Erasmus, The Education of a Christian Prince, ed. L. Jardine, transl. M. Cheshire and M.J. Heath. Cambridge: Cambridge Univesity Press.

Kelly, M. (2015) Mankind, Matter, and More: Sacred Materiality in the Tower Works of Thomas More, Moreana 52 (199-200), pp. 123-134.

Mancel, F. (2012) Rapaël Hythlodée et l'utopique Cité des Anges, Moreana 49 (187-188), pp. 183-205.

Marc'hadour, G. (2006-2007) The Three Bodies of Saint Thomas More, Moreana 43/44 (168, 169170), pp. 85-106.

Miller, C.H. (1976) Introduction, in: Thomas More, De Tristitia Christi, in 2 vols., The Complete Works of St. Thomas More 14, vol. 2. New Haven and London: Yale University Press, pp. 693778.

More, T. (1961) Selected Letters, ed. E.F. Rogers. New Haven and London: Yale University Press.

More, T. (1965) Utopia, ed. E. Surtz, S.J., and J.H. Hexter. The Complete Works of St. Thomas More 4. New Haven and London: Yale University Press.

More, T. (1976) A Dialogue of Comfort, ed. L.L. Martz and F. Manley. The Complete Works of St. Thomas More 12. New Haven and London: Yale University Press.

More, T. (1976b) De Tristitia Christi, in 2 vols., ed. C.H. Miller, The Complete Works of St. Thomas More 14. New Haven and London: Yale University Press.

More, T. (1993) The Sadness of Christ, ed. G. Wegener. New York: Scepter.

More, T. (2005) Utopia, ed. Wayne A. Rebhorn, transl. Ralph Robinson. New York: Barnes \& Noble.

Mulliez, J. (2006-2007) De l'Importance du Corps dans l'Utopie, Moreana 43/44 (168, 169-170), pp. 204-221.

Panizza, L. (1995) Valla's De voluptate and Erasmus' Stultitiae Laus: Renewing Christian Ethics, Fifth-Annual Margaret Mann Phillips Lecture 1992, Erasmus of Rotterdam Society Yearbook 15, pp. 1-25.

Phélippeau, M.-C. (2015) Thomas More, the Mystic?, Moreana $5^{2}$ (199-200), pp. 135-154.

Rummel, E. (1988) Introductory note, in: D. Erasmus, On Disdaining the World, in: Collected Works of Erasmus, vol. 66, ed. J.W. O'Mally. Toronto, Buffalo, and London: University of Toronto Press.

Seebohm, F. (1971) The Oxford Reformers John Colet, Erasmus, and Thomas More: Being a History of Their Fellow-Work. London: Longman's, 1867, 1887 / Reprint New York: AMS Press.

Sissa, G. (2012) Familiaris reprehensio quasi errantis. Raphael Hythloday, between Plato and Epicurus, Moreana 49 (187-188), pp. 121-150.

Steel, C. (2009) Erasmus and Aristotle, in: E. Pasini and P.B. Rossi (eds), Erasmo da Rotterdam e la Cultura Europea / Erasmus of Rotterdam and European Culture. Millennio Medievale 79. Firenze: Sismel - Edizioni del Galluzzo, pp. 149-174.

Tracy, J.D. (1972) Erasmus: The Growth of a Mind. Genève, Droz.

Trapp, J.B. (1991) Erasmus, Colet and More: The Early Tudor Humanists and their Books. The Panizzi Lectures 1990. London: The British Library.

Turner, P. (2003) Introduction, in: T. More, Utopia, ed. Paul Turner. London: Penguin.

Van Ruler, H. (2009a) The Philosophia Christi, its Echoes and its Repercussions on Virtue and Nobility, in: A.A. MacDonald, Z.R.W.M. von Martels and J.R. Veenstra (eds), Christian Humanism: Essays in Honour of Arjo Vanderjagt. Leiden and Boston: Brill, pp. 235-263.

Van Ruler, H. (2009b) 'Quid aliud est, quam insanire?' Erasmus, Valla and the Stoic-Epicurean Controversy, in: E. Pasini and P.B. Rossi (eds), Erasmo da Rotterdam e la Cultura Europea / Erasmus of Rotterdam and European Culture. Millennio Medievale 79. Firenze: Sismel Edizioni del Galluzzo, pp. 175-197.

Vermeir, M.M.K., Brabantia: Decoding the main characters of Utopia, Moreana 49 (187-188), pp. 151-181.

Yoran, H. (2010) Between Utopia and Dystopia: Erasmus, Thomas More, and the Humanist Republic of Letters. Lanham: Lexington. 


\begin{abstract}
About the author
Han van Ruler is professor of Intellectual History of the Renaissance and the Baroque at Erasmus University Rotterdam. He is general editor of Brill's Studies in Intellectual History and scientific director of the Dutch Research School of Philosophy. Han van Ruler co-edited the Dictionary of Seventeenth and Eighteenth Century Dutch Philosophers (Bristol: Thoemmes Press, 2003) and has made various modern editions of seventeenth-century philosophical sources. He is presently preparing a book on Erasmus's moral philosophy.
\end{abstract}


